Новічкова Тамара Петрівна кандидатка технічних наук, доцентка кафедри готельно-ресторанного бізнесу Одеської національної академії харчових технологій, вул. Канатна, 112, м. Одеса, 65039, тел.: (050) 654-49-58, e-mail: tamarakoled@gmail.com, https://orcid.org/0000-0001-6133-9882

Лебеденко Тетяна Свгенівна докторка технічних наук, професорка кафедри готельно-ресторанного бізнесу Одеської національної академії харчових технологій, вул. Канатна, 112, м. Одеса, 65039, тел.: (098) 336-01-30, https://orcid.org/0000-0001-8385-4674

Асауленко Наталя Валеріанівна старша викладачка кафедри готельноресторанного бізнесу Одеської національної академії харчових технологій, вул. Канатна, 112, м. Одеса, 65039, тел.: (097) 975-03-88, https://orcid.org/0000-0001$7057-4614$

\title{
СЕРВІСНІ ПОСЛУГИ: КЕЙТЕРИНГОВЕ ОБСЛУГОВУВАННЯ В ОРГАНІЗАЦЇ̈ РЕСТОРАННОГО ГОСПОДАРСТВА ЯК НАПРЯМ ПШДВИЩЕННЯ КОНКУРЕНТОСПРОМОЖНОСТІ В УМОВАХ КРИЗИ
}

Анотація. В даному досліджені проведено аналіз системи управління конкурентоспроможністю закладу ресторанного господарства, пошук та обгрунтування шляхів для збільшення рівня конкурентоспроможності в умовах кризи. Узагальнено погляди рівних авторів, проведено критичний аналіз наукових джерел стосовно визначенню сутності поняття «конкурентоспроможність підприємства», зроблено висновок, що дана економічна категорія є складною та не має єдиного тлумачення.

Із проведеного аналізу, щодо чинників впливу зовнішнього середовища на конкурентоспроможність підприємств ресторанного бізнесу визначено, що політична, економічна ситуація в Україні на сучасному етапі функціонування характеризується негативними тенденціями. Для більш детального аналізу стратегічних факторів зовнішнього середовища проєктуємого ресторану «Delicatering» проведено EFAS-аналіз, аналіз готовності підприємства реагувати на стратегічні фактори зовнішнього середовища. Для оцінки конкурентоздатності підприємства, яке проєктується в даній сфері бізнесу проведено аналіз конкурентів. Для визначення основних споживачів кейтерингових послуг було 
проведене опитування в соціальній мережі «Facebook» за допомогою Google Forms.

До числа важливих стратегічних завдань розвитку ресторану «Delicatering» віднесено диверсифікацію пропозиції, розширення спектру кейтерингових послуг, зокрема, перспектива розвитку довгострокових відносин 3 постійними споживачами кейтерингових послуг; можливість збільшення доходу, отриманого від клієнта: важливо не тільки забезпечити довгострокові відносини зі споживачами, а й максимізувати отриманий від них комерційний ефект, пріоритетність завоювання перспективних ніш і забезпечення лідерства серед конкурентів. Застосування розглянутих можливостей дозволить ресторану «Delicatering» отримати конкурентні переваги на ринку, увійти в число лідерів, а в ряді випадків завоювати ексклюзивні ринкові позиції. Розглянуті переваги від впровадження кейтерингових послуг заслуговують на увагу.

Ключові слова: проєкт, кейтерінг, обслуговування, ресторанний бізнес, інновації, розвиток, технології, послуги.

Novichkova Tamara Petrivna Candidate of Technical Sciences, Associate Professor of Hotel and Restaurant Business of the Odessa National Academy of Food Technologies, Kanatna St., 112, Odessa, 65039, tel.: (050) 654-49-58, e-mail: tamarakoled@gmail.com, https://orcid.org/0000-0001-6133-9882

Lebedenko Tetiana Yevhenivna Doctor of Technical Sciences, Professor of the Department of Hotel and Restaurant Business of the Odessa National Academy of Food Technologies, Kanatna St., 112, Odessa, 65039, tel.: (098) 336-01-30, https://orcid.org/0000-0001-8385-4674

Asaulenko Natalya Valerianivna Senior Lecturer of the Department of Hotel and Restaurant Business of the Odessa National Academy of Food Technologies, Kanatna St., 112, Odessa, 65039, tel.: (097) 975-03-88, https://orcid.org/0000-0001-7057-4614

\title{
SERVICE SERVICES: CATERING SERVICE IN THE ORGANIZATION OF THE RESTAURANT ECONOMY AS A DIRECTION OF INCREASING COMPETITIVENESS TO CONDITIONS
}

\begin{abstract}
Restaurant business is a field of activity that provides the population with culinary products and creates a high level of service in accordance with the needs of consumers, organizes leisure services. The level of development of the restaurant industry in each country is one of the economic indicators of quality of life. The restaurant business creates significant competition, which encourages its active
\end{abstract}


development, requires looking for new market segments, applying innovations, forcing to experiment to maintain competitiveness in the market, finding new customers.

This study analyzes the competitiveness management system of the restaurant, finding and justifying ways to increase the level of competitiveness in a crisis. The views of equal authors are generalized, a critical analysis of scientific sources is conducted to determine the essence of the concept of «enterprise competitiveness», it is concluded that this economic category is complex and has no single interpretation.

From the analysis of the factors influencing the external environment on the competitiveness of restaurant enterprises, it is determined that the political and economic situation in Ukraine at the present stage of operation is characterized by negative trends. For a more detailed analysis of the strategic factors of the external environment of the projected restaurant «Delicatering» EFAS-analysis, analysis of the company's readiness to respond to strategic environmental factors. To assess the competitiveness of the enterprise, which is designed in this area of business analysis of competitors. To identify the main consumers of catering services, a survey was conducted on the social network «Facebook» using Google Forms.

Among the important strategic objectives for the development of the restaurant «Delicatering» are the diversification of supply, expanding the range of catering services, in particular, the prospect of developing long-term relationships with regular consumers of catering services; the possibility of increasing the income received from the client: it is important not only to ensure long-term relationships with consumers, but also to maximize the commercial effect obtained from them, the priority of gaining promising niches and ensuring leadership among competitors. The use of these opportunities will allow the restaurant «Delicatering» to gain a competitive advantage in the market, to become one of the leaders, and in some cases to gain exclusive market positions. The considered advantages from introduction of catering services deserve attention.

Keywords: project, catering, service, restaurant business, innovation, development, technology, services.

Постановка проблеми. Ресторанне господарство - це сфера діяльності, яка забезпечує населення кулінарною продукцією та створює високий рівень обслуговування відповідно до потреб споживачів, організує послуги дозвілля. Рівень розвитку ресторанного господарства в кожній країні виступає одним із економічних показників якості життя населення. Сфера ресторанного бізнесу створює суттєву конкуренцію, що спонукає активному ii розвитку, потребує шукати нові сегменти ринку, застосовувати нововведення, змушує експериментувати для утримання конкурентоспроможності на ринку, пошуку нових клієнтів. 
Управління конкурентоспроможністю кожного окремого закладу ресторанного господарства - це важлива складова ефективного функціонування підприємства на ринку. Незнання тонкощів ресторанного бізнесу та неуважність до можливих альтернатив його розвитку не дозволяє підприємцям отримати конкурентні переваги. 3 розвитком новітніх технологій в індустрії гостинності кейтерингове обслуговування поступово набуває масштабності в організації та проведенні святкових заходів, бенкетів, під час яких приготування страв та обслуговування поєднуються 3 послугами інших сфер обслуговування. Визначення ролі кейтирингових послуг у підвищенні конкурентоспроможні підприємств ресторанного бізнесу обумовлює актуальність даного дослідження.

Аналіз останніх досліджень і публікацій. Дослідженню питань конкурентоспроможності підприємств присвячені роботи вітчизняних та зарубіжних вчених, зокрема Г. Азоєва, П. Зав’ялова, С. Покропивного, М. Портера, М. Єрмолова, А. Яновського, І. Ансоффа, Л. Калашникова, Ф. Котлера, Р. Фатхутдінова та ін. Окремі аспекти розвитку кейтерингу як форми ресторанного бізнесу висвітлювалися у працях таких науковців, як Ф. Халворсена, К. Погодіна, В. Архіпова, О. Радіонова, І. Смирнова, Н. П'ятницької та ін. Незважаючи на те, що багато науковців досліджували проблематику кейтерингу, саме особливості кейтерингу в підвищенні конкурентоспроможності означених підприємств вивчені недостатньою мірою.

Метою статті $є$ аналіз системи управління конкурентоспроможністю закладу ресторанного господарства, пошук та обгрунтування шляхів для збільшення рівня конкурентоспроможності в умовах кризи.

Виклад основного матеріалу. Сутність поняття «конкуренція» розглянуто в Законі України «Про захист економічної конкуренції», який трактує термін «економічна конкуренція» «як змагання між суб’єктами господарювання для здобуття завдяки власним досягненням переваг над іншими суб'єктами господарювання, внаслідок чого споживачі, суб'єкти господарювання мають можливість обирати між кількома продавцями, покупцями, а окремий суб'єкт господарювання не може визначати умови обороту товарів на ринку» [1].

Узагальнюючи погляди рівних авторів, проведений критичний аналіз наукових джерел стосовно визначенню сутності поняття «конкурентоспроможність підприємства», зроблено висновок, що дана економічна категорія $\epsilon$ складною та не має єдиного визначення. Кожне трактування має свої відмінності, так напряклад, А. Яновський [2] та Л. Калашнікова [Калашникова Л.М. Конкурентоспособность предприятия и их продукции. Машиностроитель. 2013. № 11. С. 15-18.], на нашу думку, не взяли до уваги фактори зовнішнього середовища. Натомість С. Балабанова [3], навпаки залишила без уваги чинники внутрішнього середовища. Отже, 
конкурентоспроможності підприємства не є абсолютним поняттям, воно може бути суттєво різним відносно конкурентів, $є$ комплексною характеристикою підприємства, яка зображає сполучення конкурентних переваг.

Якість обслуговування на підприємствах ресторанного господарства - це одна 3 найбільш актуальних тем, що хвилюють як власників, так менеджерів ресторанного бізнесу. Сервіс як культурний феномен, будучи частиною культури, створювався протягом століть під впливом матеріальних, естетичних, етичних цінностей, що задовольняють повсякденні запити людини. Поняття «сервіс» в науковій літературі має багато значень межі якого постійно розширюються в залежності від видів діяльності. Багатогранність поняття «сервіс» обумовлена багатьма причинами, у тому числі, лінгвістичними. [4].

Під ресторанним сервісом розуміється таке обслуговування, яке приносить задоволення, i не тільки відвідувачу ресторану, але i його обслуговуючому персоналу [5].

Під послугою розуміється робота (сукупність заходів), яка виконується для задоволення потреб клієнтів, володіє закінченістю і має певну вартість. Сервісна діяльність як частина соціо-економічної діяльності виявляється тісно пов'язаної 3 самими різними аспектами культурної практики -3 побутом i домашнім господарством населення, 3 практикою державно-політичного будівництва, 3 соціальними верствами і групами, 3 вихованням підростаючого покоління, а також з відпочинком і розвагами людей [6].

Через пандемію коронавірусу 2020 р. велика кількість українських кафе i ресторанів тимчасово закрилися, лише деякі продовжили працювати виключно в режимі доставки або видачі замовлень 3 собою. 3 одного боку це призвело до зростання обсягів доставки їжі (20-25 \%). На початок липня в Україні відновили роботу лише 86\% кафе та ресторанів від докризового рівня [7]. До початку пандеміі коронавірусу в Україні було понад 30000 закладів громадського харчування. В середньому, в одному працювало 35 осіб (у великих комплексах 150, в невеликих кав'ярнях - три-п’ять). Згідно опитування Української ресторанної асоціації у червні 2020 року 24 \% закладів в Україні працювали лише на літніх майданчиках. 18 \% локацій працювали на терасі, а також здійснювали доставку. 16 \% опитаних 46 респондентів зазначили, що їхній заклад працював на доставку та приймав гостей на терасах і в залі, а 13 \% відповіли, що годували гостей на літній терасі та в залах, але доставкою не займалися [7]. В залі та на доставку працювали 4 \%, тільки у залі - 6 \%, а тільки на доставку та takeaway -8 \%. 11\% опитаних зазначили, що їх заклади були повністю закриті [7].

Серед поставлених було й питання щодо виручки. Респондентів попросили вказати, який відсоток склала виручка у червні 2020 по відношенню до червня 2019 року. Так, 24 \% зазначили, що виручка, порівняно з червнем минулого року 
склала менше 20\%. 24\% позначили, що виручка склала від 21 до 40 \%, а 19 \% від 41 до 60 \%. 9\% опитаних зазначили, що їх виручка складала 61-80\%, а 8 \% опитаних отримали виручку в $81 \%$ та більше. 17 \% опитаних відповіли, що вони не здійснювали підрахунків [8]

Новий індустріальний ландшафт, створений COVID-19, змушує підприємства ресторанного бізнесу розробляти нові креативні механізми не тільки збереження життєздатності, але й розвитку, які б дали змогу адаптуватись до нових реалій зовнішнього середовища [9].

Ресторани, кафе, пекарні та інші підприємства цієї сфери в умовах боротьби 3 пандемією вимушені змінювати формат роботи 3 клієнтами. Для збереження свого іміджу, утримання постійних клієнтів та загалом присутності у сфері ресторанного бізнесу значна частина підприємств здійснила реінжиніринг основних бізнес-процесів 3 акцентом на формат адресної доставки [9]. Так, прикладом є мережа ресторанів здорового харчування «Salateira», яка, працюючи 3 міжнародною кур'єрською компанією «Glovo», вже тривалий час здійснює постачання своїх страв споживачам. Формати закладів, які раніше, в принципі, не працювали з доставкою (бари, паби, кав’ярні, заклади з караоке, кальянні), також баряться за гостей: багато хто пропонує акції та знижки за самовивіз страв i напоїв [10]. 3 огляду на це сьогодні для збереження бізнесу на перший план виносяться питання здійснення трансформацій у діяльності підприємств ресторанного бізнесу та розроблення інноваційних рішень.

Слово кетеринг походить від англійського cater - постачати провізію. Крім організації обідів (доставки готових страв і приготування їх на місці) багато кетерінговие компанії надають інші послуги, починаючи від внутрішньої i зовнішньої прибирання і закінчуючи наданням обслуговуючого персоналу. За оцінкою Deutsche Bank, світовий ринок кетерингу становить 78 млрд. євро. В Україні в зв’язку з новизною цієї послуги ринок пропозицій зайнятий не так щільно, як на Заході. Разом з тим в останні роки спостерігається збільшення попиту на виїзне обслуговування. Звідси випливає необхідність більш пильного вивчення світового досвіду та накопичення власного з боку тих підприємств громадського харчування, які припускають зайняти міцне місце в даному секторі.

Зростання числа компаній в м. Одеса, які займаються банкетами, фуршетами i оформленням заходів, свідчить про зростаючий попит на послуги в даному сегменті. Кожна 3 цих компаній пропонує свій спектр послуг: банкети на винос, фуршети, кава-брейки, барбекю, кондитерські вироби, надання технічного обладнання, декор, флористика. Разом з тим, більшість компаній займаються організацією заходів під ключ.

Український ринок кейтерингу на сьогоднішній день переважно сконцентрований у містах Києві та Одесі. На ринок Києва припадає близько 62 \% 
від загального обсягу ринку кейтерингу в Україні, на Одесу - 22 \%. Інші міста країни складають лише 16 \% від обсягу українського ринку кейтерингу (Львів, Харків). Основними причинами такої структури учасників ринку є, по-перше, те, що даний ринок історично став складатися саме в зазначених містах; по-друге, висока чисельність населення в зазначених містах України; по-третє, висока концентрація і розвиненість бізнес-інфраструктури в цих регіонах; по-четверте, частота організації і проведення різних заходів (виставки, ярмарки, конференції, корпоративи.) [11,12].

Із проведеного аналізу, щодо чинників впливу зовнішнього середовища на конкурентоспроможність підприємств ресторанного бізнесу визначено, що політична, економічна ситуація в Україні на сучасному етапі функціонування характеризується негативними тенденціями. Для більш детального аналізу стратегічних факторів зовнішнього середовища проєктуємого ресторану «Delicatering» проведено EFAS-аналіз, аналіз готовності підприємства реагувати на стратегічні фактори зовнішнього середовища (див табл. 1) [13].

Таблиия 1

Фактори впливу зовнішнього середовища

\begin{tabular}{|c|c|c|c|c|}
\hline $\begin{array}{c}\text { Зовнішні стратегічні } \\
\text { фактори }\end{array}$ & Вага & Оцінка & $\begin{array}{c}\text { Зважена } \\
\text { оцінка }\end{array}$ & Коментарі \\
\hline \multicolumn{5}{|l|}{ Можливості } \\
\hline $\begin{array}{l}\text { Створення нових } \\
\text { партнерських зв'язків }\end{array}$ & 0,18 & 4 & 0,72 & $\begin{array}{l}\text { Нові можливості для } \\
\text { реалізації ресторанного } \\
\text { обслуговування }\end{array}$ \\
\hline $\begin{array}{l}\text { Сприятливий } \\
\text { демографічний клімат }\end{array}$ & 0,08 & 3 & 0,24 & $\begin{array}{l}\text { Сприятливе бізнес- } \\
\text { середовище }\end{array}$ \\
\hline $\begin{array}{l}\text { Розвиток технологічного } \\
\text { забезпечення }\end{array}$ & 0,1 & 2 & 0,2 & $\begin{array}{l}\text { Удосконалення } \\
\text { кейтерингових послуг }\end{array}$ \\
\hline Уподобання споживачів & 0,14 & 4 & 0,56 & $\begin{array}{l}\text { Зростання попиту на } \\
\text { проведення виїзних } \\
\text { урочистостей, послуги } \\
\text { корпоративного харчування }\end{array}$ \\
\hline $\begin{array}{l}\text { Зменшення витрат } \\
\text { електроенергії }\end{array}$ & 0,01 & 3 & 0,03 & $\begin{array}{l}\text { Економія коштів за рахунок } \\
\text { енергоресурсів підприємства }\end{array}$ \\
\hline \multicolumn{5}{|l|}{ Загрози } \\
\hline $\begin{array}{l}\text { Нестабільність політичної } \\
\text { ситуації }\end{array}$ & 0,2 & 4 & 0,8 & $\begin{array}{l}\text { Зниження потоку клієнтів, } \\
\text { особливо з-за кордону }\end{array}$ \\
\hline Зростання темпу інфляції & 0,12 & 3 & 0,36 & $\begin{array}{l}\text { Зменшення попиту на } \\
\text { послуги в зв'язку з } \\
\text { нестабільністю валюти }\end{array}$ \\
\hline $\begin{array}{l}\text { Зниження активності } \\
\text { клієнтів }\end{array}$ & 0,07 & 4 & 0,28 & $\begin{array}{l}\text { Зміна в уподобаннях } \\
\text { споживачів }\end{array}$ \\
\hline
\end{tabular}




\begin{tabular}{|l|c|c|c|l|}
\hline $\begin{array}{l}\text { Спад рівня } \\
\text { конкурентоспроможності }\end{array}$ & 0,06 & 2 & 0,12 & $\begin{array}{l}\text { Вихід на ринок нових } \\
\text { конкурентів або активізація } \\
\text { існуючих }\end{array}$ \\
\hline Нестабільність курсу валют & 0,04 & 3 & 0,12 & $\begin{array}{l}\text { Додаткові витрати в зв'язку 3 } \\
\text { нестабільним курсом валюти }\end{array}$ \\
\hline Разом & 1 & & 3,43 & \\
\hline
\end{tabular}

Джерело: власна розробка авторів

На підставі проведеного дослідження можна зробити висновки, що ресторан «Delicatering» 3 оцінкою 3,43 показує середній рівень реагування на умови зовнішнього середовища. Для оцінки конкурентоздатності проєктуємого підприємства в даній сфері бізнесу проведено аналіз конкурентів. Для порівняння обрано чотири лідируючих кейтерингових компанії: «Procatering», «Bon Appetit», «Time to eat», «Nom Nom», які перебувають в даній категорії послуг. Оцінка проводитиметься за п'ятибальною шкалою, де 0 - це відсутність якості, а 5 найсильніша пропозиція. Аналіз конкурентів здійснюється за наступними критеріями: асортимент кейтерингових послуг; аналіз цінової складової; місце розташування оцінюється в залежності від того, в межах міста або за містом знаходиться заклад; рекламна активність оцінюється за наявністю реклами в журналах, на телебаченні і в соціальних мережах.

Аналіз головних конкурентів виїзного ресторанного обслуговування та організацій заходів та урочистостей в місті Одеса наведено рис. 1.

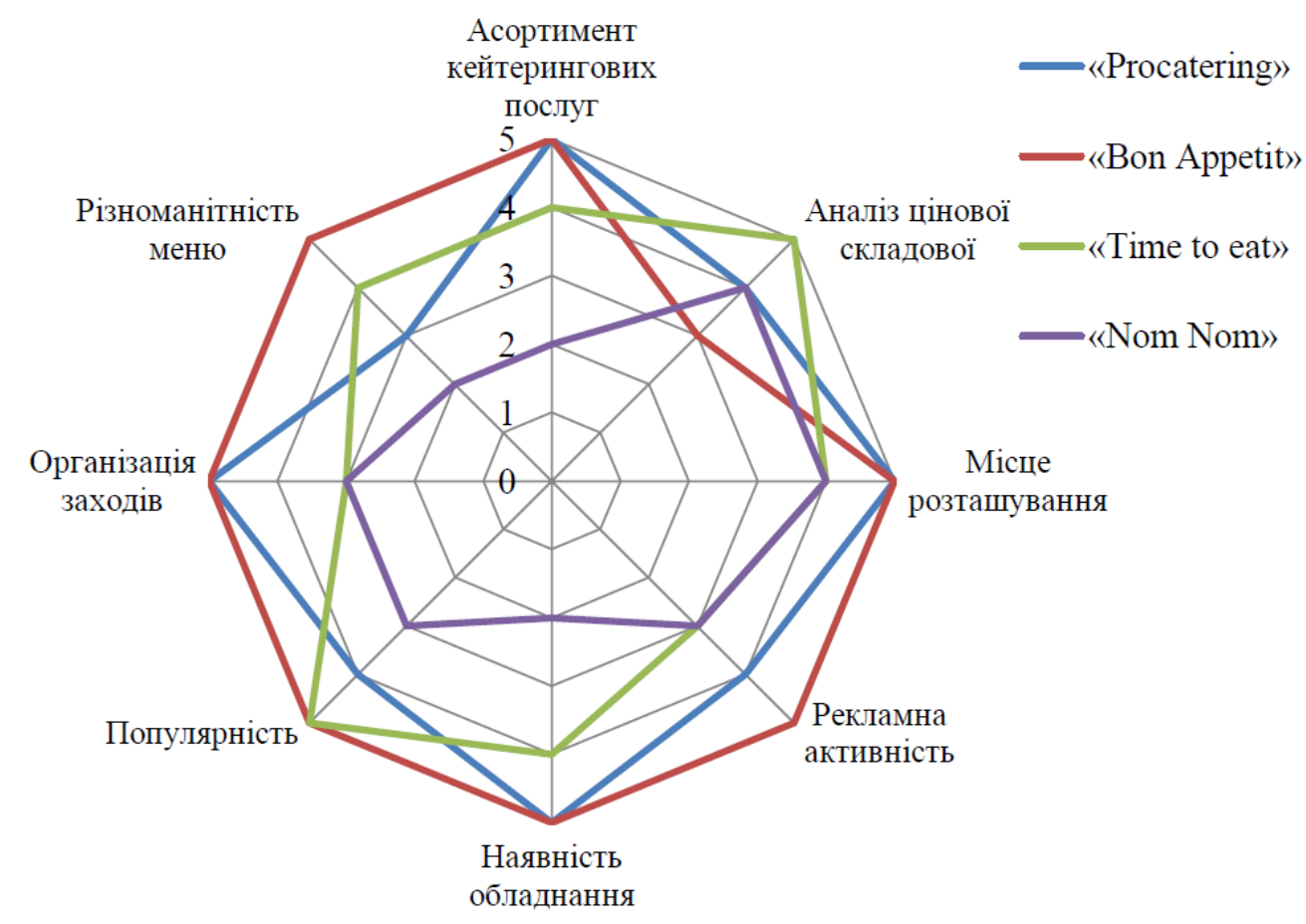

Pис. 1. Порівняння конкурентів у сфері кейтерингу м. Одеси 
Як свідчать дані рис. 1, компанія «Bon Appetit» займає лідируючі позиції за асортиментом послуг, рекламною активністю, популярністю та організацією заходів. На другому місці компанія «Procatering», яка має переваги за місцем знаходження i наявністю різноманітного меню, організацією заходів та урочистостей. Компанія «Time to eat» має переваги за ціновою складовою, «Nom Nom» має мобільну стійку і може провести захід в будь-якому місці, але через специфіку меню (морозиво, коктейлі, солодощі) популярність компанії має переважно сезонний характер.

Для визначення основних споживачів кейтерингових послуг було проведене опитування в соціальній мережі «Facebook» за допомогою Google Forms. B анкетуванні приймали участь 236 осіб. За результатами анкетування встановлено, що головними споживачами послуг є особи віком від 25 до 35 років. На другому місці - особи віком від 35 до 45 років, їх число становить $27 \%$. Третє місце особи від 18 до 25 років, або 23 \% від загального числа респондентів. Якщо розглядати замовників за статевою ознакою, то це жінки - 62 \%. При визначенні кількості респондентів, які користуються послугами кейтерингу, було отримано 43 \% позитивних відповідей респондентів та 57 \% негативних відповідей. Отже, 61 \% респондентів користуються послугами організації заходів за допомогою агентств, $39 \%$ організовують урочистості самостійно. Отже, потенційними споживачами кейтерингових послуг є бізнесмени та ділові партнери, частка яких складає 29 \%, пари - 32 \%, сім’ї з дітьми - 22 \% та компанії друзів - $17 \%$.

Оскільки в ДСТУ 4281:2004 «Заклади ресторанного господарства. Класифікація» [14], кейтеринг віднесено до підприємств ресторанного господарства, Правила роботи закладів (підприємств) ресторанного господарства № 219 [15] поширюються і на діяльність підприємств кейтерингу. Зокрема, до основних вимог, наведених в правилах і які безпосередньо мають виконуватися підприємствами кейтерингу, відносять:

1) розрахунки за продукцію й надані послуги в закладах ресторанного господарства здійснюються за готівку та/або в безготівковій формі із застосуванням реєстраторів розрахункових операцій або зареєстрованих у встановленому порядку розрахункових книжок;

2) при прийманні попереднього замовлення на обслуговування суб'єкти господарської діяльності зобов'язані гарантувати виконання його замовлення в узгоджені із замовником строки;

3) усі працівники, зайняті в ресторанному господарстві, повинні мати особові медичні книжки, професійну спеціальну освіту та повинні бути забезпечені на робочих місцях технологічними картами;

4) на торговельно-технологічне обладнання, інвентар i посуд суб'єкт 
господарської діяльності повинен мати сертифікат відповідності;

5) при виготовленні продукції повинні додержуватися технологічні режими виробництва продукції, визначених нормативною документацією [6].

Види заходів та асортимент пропонованих кейтеринг-послуг ресторану «Delicatering» наведені в табл. 2.

Табличя 2

Види заходів та асортимент кейтеринг-послуг ресторану «Delicatering»

\begin{tabular}{|l|l|}
\hline \multicolumn{1}{|c|}{ Назва заходу } & \multicolumn{1}{|c|}{ Характеристика послуг } \\
\hline $\begin{array}{l}\text { Фуршети після семінарів, } \\
\text { виставок, презентацій }\end{array}$ & $\begin{array}{l}\text { Організація обслуговування. Оформлення столів. } \\
\text { Фуршетне меню. }\end{array}$ \\
\hline Корпоративні свята & $\begin{array}{l}\text { Організація обслуговування. Організація шоу-програми. } \\
\text { Фуршетне меню. Встановлення звукового та світлового } \\
\text { обладнання. Запрошення артистів, ведучого, музичного } \\
\text { гурту. Оформлення приміщення. Спецефекти. }\end{array}$ \\
\hline $\begin{array}{l}\text { Продовження таблиці 1.9 } \\
\text { Приватні свята }\end{array}$ & $\begin{array}{l}\text { Оформлення приміщення. Організація обслуговування. } \\
\text { Бенкетне меню. Розробка індивідуального сценарію. } \\
\text { Запрошення ведучого вечора. Встановлення звукового та } \\
\text { світлового обладнання. Організація розважальної } \\
\text { програми. }\end{array}$ \\
\hline Кава-брейк & $\begin{array}{l}\text { Накриття для кава-брейку включає гарячі напої (кава, } \\
\text { чай), прохолодні напої (соки, води), сендвічі, канапе, } \\
\text { цукерки. }\end{array}$ \\
\hline Виїзний коктейль-бар & $\begin{array}{l}\text { Меню: авторські коктейлі, лимонади, смузі і настоянки. } \\
\text { Бармен-шоу. }\end{array}$ \\
\hline Барбекю & $\begin{array}{l}\text { Організація обслуговування. Меню: ситні м'ясні страви, } \\
\text { приготовані на відкритому вогні. }\end{array}$ \\
\hline Кенді-бар & $\begin{array}{l}\text { Дитяче меню. Розробка індивідуального сценарію дитячих } \\
\text { свят. Запрошення аніматорів. }\end{array}$ \\
\hline $\begin{array}{l}\text { Доставка продукції харчування } \\
\text { обладнання }\end{array}$ & $\begin{array}{l}\text { Не передбачає обслуговування офіціантами. Надання в } \\
\text { оренду посуду, келихів та іншого обладнання. }\end{array}$ \\
\hline
\end{tabular}

Джерело: власне дослідження

До числа важливих стратегічних завдань розвитку ресторану «Delicatering» доцільно вважати диверсифікацію пропозиції, розширення спектру кейтерингових послуг, зокрема:

1. Перспектива розвитку довгострокових відносин 3 постійними споживачами кейтерингових послуг. Дане завдання відповідає сучасній концепції маркетингу, суть якої полягає в утриманні, лояльності та розвитку довгострокових відносин зі споживачами.

2. Можливість збільшення доходу, отриманого від клієнта: важливо не 
тільки забезпечити довгострокові відносини зі споживачами, а й максимізувати отриманий від них комерційний ефект.

3. Пріоритетність завоювання перспективних ніш і забезпечення лідерства серед конкурентів. Розробка інноваційних послуг взаємопов'язана з такими напрямками:

- моніторинг інноваційних трендів на ринку кейтерингових послуг і якомога більш раннє їх використання;

- розробка трендів і інноваційних пропозицій за рахунок аналізу потреб потенційних споживачів i використання нестандартних методів вирішення стратегічних завдань.

4. Можливість ексклюзивного позиціонування на ринку кейтерингових послуг, формування унікального бренду. Генерація та адаптація інноваційних кейтерингових послуг на ринку повинна стати переважаючою компонентою бренду ресторану, що сприяє завоюванню лідируючих позицій. Розглянутий підхід дозволить ресторану мінімізувати витрати на комунікаційну стратегію просування, сприятиме формуванню безумовних переваг для використання системи маркетингових комунікацій зі споживачем кейтерингових послуг.

Висновки. Застосування розглянутих можливостей дозволить ресторану «Delicatering» отримати конкурентні переваги на ринку, увійти в число лідерів, а в ряді випадків завоювати ексклюзивні ринкові позиції. Розглянуті переваги від впровадження кейтерингових послуг заслуговують на увагу. Однак, необхідно враховувати можливі загрози:

1. Головна загроза полягає в значних матеріальних витратах на всіх етапах: від відкриття ресторану та конструювання кейтерингової послуги до їі реалізації, від виконання нового проекту до здійснення перетворень в процесах управління рестораном.

2. Загроза, яка носить внутрішній характер, полягає в складності побудови системи управління рестораном.

3. Негативні наслідки економічної кризи. Загальна економічна ситуація в країні без сумніву накладає свій слід - заборона на ввезення імпорт продуктів, подорожчання вітчизняних інгредієнтів, зростання комунальних та транспортних витрат, збільшення витрат на заробітну плату i податки, а також падіння добробуту населення негативно відбивається на сфері громадського харчування.

\section{Jimepamypa:}

1. Закон України «Про захист економічної конкуренції» від 11 січня 2001 р. № 2210. URL: http://zakon0.rada.gov.ua/laws/show/2210-14 (дата звернення 12.01.2021).

2. Яновский А. Конкурентоспособность товара и товаропроизводителя. БизнесИнформ. 2018. № 5. С. 21-23.

3. Балабанова Л. В. Управление конкурентоспособностью предприятий на основе 
маркетинга : [монография]. Донецк: ДонГУЭТ им. М. Туган-Барановского, 2014. 147 с.

4. Аванесова Г. А. Сервисная деятельность: историческая и современная практика, предпринимательство, менеджмент: учеб. пособ. М.: Аспект Пресс, 2016. 320 с.

5. Морозова Н. С. Реклама в социокультурном сервисе и туризме: учеб. М.: Издател. Центр «Академия», 2018. 288 с.

6. Безрученков Ю. В. Формування професійної культури майбутніх фахівців сфери ресторанного господарства у вищому навчальному закладі освіти. Луганськ. 2014. 20 с.

7. Вплив COVID-19 та карантинних обмежень на економіку України URL: https://www.kas.de/documents/270026/8703904.pdf (дата звернення 04.02.2021).

8. Як COVID-19 вплинув на рітейлерів в Україні? URL: https://www2.colliers.com/ukUA/Research/2020-05-14-Survey-of-retailers-of-Ukraine ～(дата звернення 04.02.2021).

9. Ресторан після карантину: як налагодити роботу й залучити гостей. URL: https://mind.ua/openmind/20211376restoran-pislya-karantinu-yak-nalagoditi-robotu-j-zaluchitigostej (дата звернення 07.02.2021).

10. Результати опитування операторів ресторанного ринку. URL: https://www.uara.org.ua/post/results-of-ananonymous-survey-of-restaurant-operators (дата звернення 17.02.2021).

11. Нестеренко О. О. Класифікація кейтерингових послуг для організації їх обліку. Бізнесінформ. 2019. № 4. С. 255.

12. Ф. Халворсен Основы кейтеринга: как организовать выездное обслуживание. М. : Ресторан. ведомости, 2015.

13. Шалімов О. В. Збірник рецептур національних страв та кулінарних виробів: Для підприємств громад. харчування всіх форм власності. К.: А.С.К. 2017. 848 с.

14. Заклади ресторанного господарства. Класифікація: ДСТУ 4281:2004. (Чинний від 2004-07-01). К. : Держспоживстандарт України, 2004. 18 с.

15. Правила роботи закладів (підприємств) ресторанного господарства. URL: http://zakon5.rada.gov.ua/laws/show/z0680-02 (дата звернення 25.02.2021).

\section{References:}

1. Zakon Ukrayiny «Pro zaxyst ekonomichnoyi konkurenciyi» vid 11 sichnya 2001. [Law of Ukraine «On Protection of Economic Competition»] (n.d.). kmu.gov.ua. Retrieved from: http://zakon0.rada.gov.ua/laws/show/2210-14 [in Ukrainian].

2. Yanovskyj A. (2018). Konkurentosposobnost tovara y tovaroproyzvodytelya [Competitiveness of the product and the manufacturer]. Byznes-Ynform. 2018. Vol. 5.p. 21-23. [in Russian].

3. Balabanova L. V. (2014). Upravlenye konkurentosposobnostyu predpryyatyj na osnove marketynga : [monografyya] [Marketing-Based Enterprise Competitiveness Management: [monograph]]. Doneczk: DonGUЭT ym. M. Tugan-Baranovskogo. 147 p. [in Russian].

4. Avanesova G. A. (2016). Servysnaya deyatelnost: ystorycheskaya y sovremennaya praktyka, predprynymatelstvo, menedzhment: ucheb. posob. [Service activity: historical and modern practice, entrepreneurship, management: textbook. manual.] M.: Aspekt Press. 320 p. [in Russian].

5. Morozova N. S. (2018). Reklama v socyokulturnom servyse y turyzme: ucheb.[Advertising in socio-cultural service and tourism: textbook.] M.: Yzdatel. Centr «Akademyya». 288 p. [in Russian].

6. Bezruchenkov Yu. (2014). Formuvannya profesijnoyi kultury majbutnix faxivciv sfery 
restorannogo gospodarstva u vyshhomu navchalnomu zakladi osvity [Formation of the professional culture of the Maybut fahivts in the sphere of the restaurant government at the head of the state]. Lugansk. 20 p. [in Ukrainian].

7. Vplyv COVID-19 ta karantynnyx obmezhen na ekonomiku Ukrayiny [Infusion of COVID19 and quarantine into the economy of Ukraine]. www.kas.de. Retrieved from: https://www.kas.de/documents/270026/8703904.pdf. [in Ukrainian].

8. Yak COVID-19 vplynuv na ritejleriv v Ukrayini? [Impact of COVID-19 and quarantine restrictions on the economy of Ukraine]. www2.colliers.com. Retrieved from: https://www2.colliers.com/ukUA/Research/2020-05-14-Survey-of-retailers-of-Ukraine [in Ukrainian].

9. Restoran pislya karantynu: yak nalagodyty robotu j zaluchyty gostej [Restaurant after quarantine: how to set up work and attract guests]. mind.ua. Retrieved from: https://mind.ua/openmind/20211376- restoran-pislya-karantinu-yak-nalagoditi-robotu-j-zaluchitigostej [in Ukrainian].

10. Rezultaty opy 'tuvannya operatoriv restorannogo rynku [Results of the survey of restaurant market operators]. uara.org.ua Retrieved from: https://www.uara.org.ua/post/results-of-ananonymoussurvey-of-restaurant-operators. [in Ukrainian].

11. Nesterenko O. O. (2019). Klasyfikaciya kejteryngovyx poslug dlya organizaciyi yix obliku [Classification of catering services for the organization of their accounting.]. Biznesinform. Vol. 4. p. 255. [in Ukrainian].

12. F. Xalvorsen (2015). Osnovi kejterynga: kak organyzovat viezdnoe obsluzhyvanye [Catering Basics: How to Organize Catering Services]. M.: Restoran. Vedomosty. p. 315. [in Russian].

13. Shalimov O. V. (2017). Zbirnyk receptur nacionalnyx strav ta kulinarnyx vyrobiv: Dlya pidpryyemstv gromad. xarchuvannya vsix form vlasnosti [Collection of recipes of national dishes and culinary products: For community enterprises. food of all forms of ownership]. K.: A.S.K. 848 p. [in Ukrainian].

14. Zaklady restorannogo gospodarstva. Klasyfikaciya: DSTU 4281:2004. (Chynnyj vid 200407-01). [Pledge the restaurant industry. Classification: DSTU 4281: 2004. (Chinniy vid 2004-07-01)] K. : Derzhspozhy`vstandart Ukrayiny. 2004. 18 p. [in Ukrainian].

15. Pravyla roboty zakladiv (pidpryyemstv) restorannogo gospodarstva [Rules of work of establishments (enterprises) of restaurant economy]. zakon5.rada.gov.ua. Retrieved from: http://zakon5.rada.gov.ua/laws/show/z0680-02. [in Ukrainian]. 